\title{
Reverse "Y" Shape Fistula - a Paricularity in the Evolution of Postanal Space Abscesses
}

\author{
DANIEL ION ${ }^{1,2}$, FLORENTINA MUȘAT ${ }^{2}$, ALEXANDRA BOLOCAN ${ }^{1,2}$, BOGDAN SOCEA $^{1,3}$, \\ OCTAVIAN ANDRONIC ${ }^{1,2 *}$, DAN NICOLAE PĂDURARU ${ }^{1,2}$ \\ ${ }^{1}$ Carol Davila University of Medicine and Pharmacy, 37 Dionisie Lupu, 020021, Bucharest, Romania \\ ${ }^{2}$ Emergency University Hospital of Bucharest, 169 Splaiul Independentei, 050098, Bucharest, Romania \\ ${ }^{3}$ Sf. Pantelimon Emergency Clinical Hospital, 340 Sos. Pantelimon, 021659, Bucharest, Romania
}

\begin{abstract}
Horseshoe fistula, with an incidence of less than $3 \%$ of the total perianal fistulas, is an atypical lesion not included in the classification of Parks. Its specificity is given by the anatomical features of the postanal space, respectively the presence of the anococcygeal ligament. This type of perineal fistula has a particular tract in shape of a reverse , $Y$ ”. We present the cases of 12 patient diagnosed with posterior horseshoe fistula with deep postanal space abscess surgically treated during 2013-2017. The study is retrospective and observative and it includes the history of the disease, the diagnostic methods, the surgical procedures performed and the postoperative evolution. As far as we are concerned, we based our approach on the advancement flap literature data, as well as on the role of the anococcygeal ligament in the pathology of this lesion type. After optimal control of the purulent collection from the postanal space and after the remission of local inflammatory phenomena, a correct advancement flap technique succeeds most often to resolve the septic area of the crypt of origin. We believe that current standards on the functional outcomes of these types of lesions require techniques that avoid the slow elastic cutting of the sphincter, minimizing the risk of incontinence.
\end{abstract}

Keywords: postanal space abscess; anococcygeal ligament; horseshoe fistula; advancement flap

Perianal abscesses represent the most common surgical pathology of this region. Their evolution, regardless of whether drainage takes place spontaneously or surgically, results in the occurrence of a chronically suppurative tract in over $25 \%$ of the cases. The ethyopathogeny of abscess is proved to be connected with the existence of the anal crypts and the Hermann Desfosses glands. The surgical treatment aims at suppressing the suppurative tract, suppressing the primary opening with preservation of the anal sphincter complex functionality. Hoseshoe fistula, with an incidence of less than $3 \%$ of the total perianal fistulas [1], is an atypical lesion not included in the classification of Parks [2]. Its specificity is given by the anatomical features of the postanal space, respectively the presence of the anococcygeal ligament. This type of perineal fistula has a particular tractin shape of a reverse „Y” [3]. We present our management of this rare lesion in a case series.

\section{Experimental part}

Materials and method

We present the cases of 12 patient diagnosed with posterior horseshoe fistula with deep postanal space abscess surgically treated during 2013-2017. The study is retrospective and observative and it includes the history of the disease, the diagnostic methods, the surgical procedures performed and the postoperative evolution.

Description of the technique

Of all peri-ano-rectal spaces known as possible areas for suppuration dispersal, the postanal space has, as a particular anatomical element, the anococcygeal ligament placed sagittal on the median line. This ligament divides the postanal space into two symmetrical halves: right and left. The suppurative process started from the posterior anal crypts usually passes through the lower third of the sphincter, producing a bilocular collection that spontaneously fistulates to the skin by making,according to Goodsall's rule, a curved fistula tract.

In the case of non-fistulized post-anal abscess, diagnosis is relatively difficult before the occurrence of obvious local inflammatory signs and exploration under anesthesia reveals the characteristic projection of the ano-coccygeal raphe. The identification of the crypt of origin, located in the posterior wall in over $90 \%$ of cases, can be done after its edematous or purulent aspect. The slight compression of the subcutaneous collection may provide clues in this regard.

*email:andronicoctavian@gmail.com, Phone: +40724024019. 
Under the control of the left hand index inserted into the anal canal, the incision arched outside the sphincter boundaries, evacuates and reunites the two halves of the collection, provided the anococcygeal ligament is sectioned at its full height. One can thus reach above the bifurcation point of the initial fistulous tract at the external limit of the external anal sphincter. Whenever it is possible to identify the transsphincteric fistula tract, a drainage seton is placed at this level for at least 6-8 weeks.

In the case of fistulized postanal abscess, there are usually two orifices placed in the posterior half of the anococcygeal raphe. Exploration with hydrogen peroxide shows the communication of both orifices with the crypt of origin in the posterior wall. Next, the arched incision that connects the two orifices and penetrates into the postanal space dividing the anococcygeal raphe is performed as in the first lesion variant. Placing the drainage seton follows the same pattern and duration as previous described.

In both situations postoperative care and follow-up respect the same pattern - local care until the remission of local inflammatory signs and granulation tissue development.

Closure of the primary opening by the mucosal advancement flap technique.

In case of failure of this technique (flap necrosis) followed by relapse, the solution was the use of slow elastic cutting seton.

\section{Results and discussions}

In this case series, there were 10 men and 2 women, with a mean age of 46.41 years and values between 36 and 61 years. The interval from the onset to the diagnosis of certainty was between 10 days - 2 years, the diagnosis being clinical or imagistic. For patients with relapse, a possible diagnosis of intestinal inflammatory disease was not confirmed by colonoscopy. The results of the proposed management were favorable, both in terms of relapse and preservation of the sphincter function (Table 1).

Table 1

CHARACTERISTICS OF THE ANALYZED CASE

\begin{tabular}{|c|c|c|c|c|c|c|c|c|}
\hline \multirow{2}{*}{$\begin{array}{l}\text { Case no. } \\
\text { (sex, age) }\end{array}$} & \multirow{2}{*}{ Admitting diagnosis } & \multirow{2}{*}{$\begin{array}{l}\text { Onset - } \\
\text { diagnosis } \\
\text { interval }\end{array}$} & \multirow{2}{*}{$\begin{array}{l}\text { Main element } \\
\text { of diagnosis }\end{array}$} & \multirow{2}{*}{$\begin{array}{c}\text { Tracts } \\
\text { no. }\end{array}$} & \multirow{2}{*}{$\begin{array}{l}\text { Drainage - } \\
\text { advancement } \\
\text { flap interval } \\
\text { (weeks) }\end{array}$} & \multirow{2}{*}{$\begin{array}{c}\text { Failure of } \\
\text { advancement } \\
\text { flap/drainageseton }\end{array}$} & \multicolumn{2}{|c|}{$\begin{array}{l}\text { Postoperative follow-up after } \\
6 \text { month/1 year } \\
\text { Relapse /sphincter function }\end{array}$} \\
\hline & & & & & & & Relapse & Sphincter function* \\
\hline $1(\mathrm{M}, 46)$ & Postanal abscess & 10 days & Clinical & 0 & 6 & No & - & +++ \\
\hline $2(\mathrm{M}, 54)$ & Postanal abscess & 14 days & Clinical & 0 & 6 & No & - & +++ \\
\hline $3(\mathrm{M}, 52)$ & Postanal abscess & 20 days & $\begin{array}{c}\text { Ultrasonograph } \\
y\end{array}$ & 0 & 5 & No & - & +++ \\
\hline $4(F, 42)$ & Spontaneous fistula & 2 months & Clinical & 2 & 4 & No & - & +++ \\
\hline $5(\mathrm{M}, 38)$ & Spontaneous fistula & 3 months & Clinical & 2 & 4 & No & - & +++ \\
\hline $6(\mathrm{M}, 61)$ & Spontaneous fistula & 3 months & Fistulography & 2 & 5 & No & - & +++ \\
\hline $7(\mathrm{M}, 48)$ & Spontaneous fistula & 6 months & MRI & 3 & 6 & No & - & +++ \\
\hline $8(F, 49)$ & $\begin{array}{c}\text { Fistula after surgical } \\
\text { drainage }\end{array}$ & 2 months & Clinical & 2 & 5 & No & - & +++ \\
\hline $9(\mathrm{M}, 36)$ & $\begin{array}{c}\text { Fistula after surgical } \\
\text { drainage }\end{array}$ & 4 months & $\mathrm{MRI}$ & 2 & 6 & No & - & +++ \\
\hline $10(\mathrm{M}, 51)$ & Relapsing fistula & 1 year & Fistulography* & 2 & 6 & Yes & - & ++ \\
\hline $11(\mathrm{M}, 39)$ & Relapsing fistula & 1 year & Fistulography $_{*}^{*}$ & 2 & 5 & No & - & +++ \\
\hline $12(\mathrm{M}, 41)$ & Relapsing fistula & 2 years & $\mathrm{MRI}^{* *}$ & 3 & 8 & Yes & - & ++ \\
\hline
\end{tabular}

$*+++=$ normal $++=$ mild / temporarily impaired

** Pre or postoperative colonoscopies performed in 3 cases of recurrent fistula excluded the presence of an inflammatory bowel diseas

In the classical classification of Parks, the reverse Y-shape fistula is not explicitly highlighted and can be classified as type 2,transsphincteric fistula localized on the posterior wall of the anal canal. This position of the suppurative process on both sides of the anococcygeal ligament gives it evolutionary and therapeutic particularities. The classic solution provided by Hanley over 50 years ago [4] consists of a vertical median incision starting from the crypt of origin which opens the postanal space and divides the subcutaneous part of the external sphincter. Basically, there is a transsfincteric fistulotomy that flattens both the fistula tract and the cavity of the postanal abscess. In his original article, Hanley argues that the internal / primary fistula is located about $1 \mathrm{~cm}$ from the lower edge of the internal sphincter so that cutting it together with the 
corresponding portion of the external sphincter (subcutaneous beam) provides healing with minimal damage of the sphincter function.

As far as we are concerned, we based our approach on the advancement flap literature data, as well as on the role of the anococcygeal ligament in the pathology of thislesiontype. We consider that the horizontal incision fulfills several purposes: it brings together the two fistulous tracts and the two compartments of the postanal space; it reaches cranial at the bifurcation point of the fistula tract;it does not affect the sphincter apparatus in any way.

The role of the transsphincteric seton is to drain the remaining tract, which will be managed later together with the advancement flap closure of the primary orifice. We believe that current standards on the functional outcomes of these types of lesions require techniques that avoid the slow elastic cutting of the sphincter, minimizing the risk of incontinence.

Colonoscopy should make the etiologic differential diagnosis with nonspecific colonic inflammatory diseases (like Crohn's disease), which can affect the entire digestive tract [5], especially in the case of relapsed fistulas.

The surgical procedure could be done even under local anesthesia [6].

\section{Conclusions}

This type of lesion deserves to be individualized for several reasons: more difficult clinical diagnosis, more frequent need for imagistic exploration and the tendency towards a branched tract due to the presence of the anococcygeal ligament - an essential anatomical element in surgical management. After optimal control of the purulent collection from the postanal space and after the remission of local inflammatory phenomena, a correct advancement flap technique succeeds most often to resolve the septic area of the crypt of origin.

Acknowledgements: All authors have contributed equally in writing, reading and approving the final manuscript.

\section{References}

1.ARNOUS J, DENIS J, PUY-MONTBRUN T, Concours Med., 12, 1980, p. 1715.

2.PARKS AG, GORDON PH, HARDCASTLE JD, Br. J. Surg., 63, no. 1, 1976, p. 1.

3.UMOH NJ, Clin. Surg., 2, no. 1570, 2017, p. 1.

[4.HANLEY PH, Dis. Colon Rectum, 8, no. 5, 1965, p, 364.

5.POPA CC, BADIU DC, ANDRONACHE LF, COSTEA RV, NEAGU SI, PANTEA STOIAN A, SOCEA B, IONESCU D, Rev. Chim. (Bucharest), 70, no. 1,2019 , p. 331.

6.DIMITRIU MCT, IONESCU CA, GHEORGHIU DC, SOCEA LI, BRATU OG, CONSTANTIN VD, PLES L, NEACSU A, BOBIC S, SOCEA B, Rev. Chim. (Bucharest), 69, no. 9, 2018, p. 2391.

Manuscript received: 28.10 .2019 
REV.CHIM.(Bucharest) $\bullet 70$ no. $12 \downarrow 2019$

http://www.revistadechimie.ro 